industry during the past few years, but their investigation has proved very perplexing because of the variety of symptoms produced. At the Institute the possible transmissibility of the disorders has been particularly studied, and in recent experiments, which were demonstrated, evidence of artificial transmission and natural spread following the inocula. tion of beds has been obtained. Of special interest in the Virology Department's programme, which is about to be greatly expanded, was the success achieved in rooting meristem cultures of carnations and transferring them to conventional growing media; this work has been undertaken as a prelude to the investigation of heat therapy for carnation virus diseases.
The Crop Protection Department (Mr. W. H. Read) had a striking demonstration of the effect of captan in protecting tomato plants from Didymella stem rot. A glasshouse trial showing the value of the chemical soil sterilizing agents, metham and chloropicrin, in comparison with steaming, was also on view.

Among the current activities of the Statistics Section (Mr. D. Cooke) attention was directed to a survey that is to be carried out, in collaboration with Rothamsted Experimental Station and the Ministry of Agriculture, on the tomato varieties in commercial cultivation in relation to earliness and district. This should provide information of particular interest in connexion with the breeding programme and experimental work generally.
F. W. TOOVEY

\title{
STUDIES IN RECREATION
}

$\mathrm{U}$ NDER the title "After Work: Leisure and Learning in Two Towns", the National Institute of Adult Education has published, for the Manchester and District Advisory Council for Further Education, studies in Bolton and Rochdale by Mr. R. Ruddock and Dr. A. Wilson (pp. 63. London: National Institute of Adult Education, 1959. 3s. 6d.). Prof. R. D. Waller contributes an introduction explaining the purpose and basis of the two surveys, which give special attention to the twenty to thirty age group, and suggesting a few generalizations. Dr. Wilson's survey of Rochdale started a few months later than Mr. Ruddock's survey of Bolton, and he stresses the quality and quantity of educational and cultural activity in this town of some 86,770 inhabitants. While this is probably not less than that of any other industrial town of comparable size in Great Britain probably as many as 40 per cent of young adults have no connexion with any organization outside their job and home. The Rochdale Literary and Scientific Society, founded in 1878, has always had the backing of influential scientists, doctors, teachers and others and often exercised considerable influence in educational and cultural matters; its membership has fluctuated between 233 and 350 during the first half of this century, but has since reached 650 . Nevertheless, apart from societies promoting religious, musical, dramatic or highly specialized loisure pursuits, the voluntary societies have little success in attracting people in the 18-35 age group, and during the past five years the membership of voluntary societies has fallen by 12-13 per cent.

The survey suggests that some of the young adults would welcome the opportunity to live a fuller social life and that others might adopt a similar attitude if parents, school-teachers and employers broadened their horizons and developed their latent interests in society and the problems which face its responsible citizens. Dr. Wilson suggests that the links between technical students and liberal or non-vocational studies could be developed, for example, by residential courses organized by the Extra-Mural Department of the University of Manchester. Nor is full use yet made of the facilities for further education under the part-time day release scheme : with a school population of 12,287 in sixty schools, day release from 2,289 technical college students is only 943,76 from 243 School of Art students, and 19 from 1,883 Further Education Centre students.
For Bolton, with approximately double the population $(163,800)$, the statistical picture is similar. The population per acre, rates per head and birthrate are very similar : there are 25,374 students in 102 schools and the total expenditure on education is roughly double $(£ 2,278,812$ compared with $£ 1,115,567)$. Of the 6,700 technical college students, 2,800 are day release, but there is no day release among 748 School of Art students and 2,700 Further Education Centre students. Like Rochdale, Bolton is becoming less dependent on the textile industry, and employment in the textile industries has dropped to less than 25 per cent of the working population, compared with 47 per cent in Rochdale. Mr. Ruddock estimates that the voluntary societies contribute only perhaps one-twentieth to the cultural activity of Bolton and that the whole cultural life of Bolton is sustained by some 6,000 of its eitizens. Among the suggestions he makes, all concerned with the upper 30 per cent of the population, in the educational sense, is extended publicity to ensure that more young adults know of the Workers' Educational Association and other serious organizations in the cultural field. Many premises require improving and equipment. The Central Library is admirably situated for sponsoring experimental provision, and although there is much good teaching of the plastic arts in Bolton, local amateurs could benefit by experience of a more exciting and vital practice which might be offered from outside. Besides the provision of special courses for those conducting classes and meetings, Mr. Ruddock suggests that the many graduate teachers, lawyers, doctors, ministers, scientists and administrators in Bolton might be encouraged to associate more freely and that executive members of local businesses would gain much from organized group contacts with specialists in science, administration, education and social science, many of whom could be reached through the University Extra-Mural Department or Bolton Technical College.

Prof. Waller points out that neither survey says much about the large undifferentiated mass - what its members' spare-time activities are, what could be done to interest them and involve them in socially healthy and worth-while pursuits. Both surveys support explicitly and implicitly Dr. I. Trenaman's conclusion, that all cultural and educational activities touch only about half of the population, and that 
half includes all those who have received higher education. It is the late school leavers who are the most likely to carry on cultural interests into mature life, and there seems good reason to believe that longer schooling, the sensible organization of continuation work and youth activities and the liberal treatment of vocational training would all considerably affect cultural and intellectual interests in later life. Prof. Waller also notes Dr. Wilson's observation that those of the $20-30$ age group who are most deeply addicted to television seem to have taken no course since leaving school, have no connexion with church or voluntary society and no interest in any other local society and organization. Possibly only television could induce any desire to participate in communal activities among this group. While the position of established societies and organizations varies - the thriving state of the Bolton branch of the Workers' Educational Association contrasts with a decline of 12-13 per cent of the membership of the Rochdale branch during the past five years-all seem likely to gain from an improved educational system and a better developed service of youth. All would be helped by better and co-operative publicity, perhaps with the assistance of local authorities, and all would be greatly strengthened by public provision of central premises, available to them all without crippling rental charges.

\section{MARITAL FERTILITY IN ENGLAND AND WALES}

\begin{abstract}
THE census of 1951 was the first general census since 1911 to include questions relating to the fertility of married women of England and Wales. The answers to these questions have been analysed in the fertility report which has recently been published (Census 1951 : England and Wales. Fertility Report. Pp. cxi +251 . London : H.M. Stationery Office, 1959. $£ 410 s$. net).

The analysis of fertility movements has become of increasing interest to demographers and other social scientists for a number of reasons. In the first place, fluctuations in marital fertility and long-term changes in the fertility-rate have most important effects on the size and structure of the population, particularly in low-mortality areas like Great Britain. Secondly, differences in the fertility of various sub-groups of the population are of considerable sociological interest by themselves, and changes in differential fertility may throw important light on other aspects of social change. It is thus likely that questions on marital fertility will figure in future British censuses as a matter of routine.
\end{abstract}

The growth of interest in fertility has also led to considerable developments in the method of analysis, in particular, the use of cohort analysis in which the fertility experience of a group of women who were either born or married in the same calendar year is traced throughout their reproductive lives. This method of analysis was used in the statistical reports of the Royal Commission on population, and is now also applied in the Fertility Report in discussing the problem of population replacement.

The fertility questions asked in the 1951 census were limited to married women under the age of fifty at the time of the census. These were asked to state the date of their marriage (and their first marriage, if married more than once), the number of live-born children, and whether they had given birth to a live-born child in the twelve months preceding the census. In addition, the census schedule contained the woman's age, and, if her husband was enumerated on the same schedule, particulars relating to his occupation. In order to simplify the analysis, a sample of 20 per cent of the 7.4 million married women was selected for analysis : an 80 per cent sample of women aged $45-49$ was taken to obtain more detailed data on completed fertility. A complete analysis was made of all women who had been married more than once, but such women constituted only $4 \cdot 1$ per cent of all married women.
The fertility report aims to answer three questions. First, what is the current level of marital fertility in England and Wales? Secondly, what differences in fertility between various groups may be detected from the data? Lastly, what are the implications of present trends on population replacement?

It will be convenient to deal with the last topic first. It is interesting to note official recognition of the fact that the question as put is incapable of being given a definite answer. On p. xci of the report a number of different hypothetical replacement-rates, calculated on different assumptions, are put forward, varying between 0.965 and 1.084 . The official comment is that "current habits imply in the long run approximately full replacement of one generation by the next and possibly very little more" (p. xcii). This is a far cry from the position in the 1930's when warnings about incipient rapid population decline were common. To be fair, however, it should be pointed out that women born in the early years of the century did not have sufficient children to replace themselves (women born between 1903-8 had a generation replacement-rate of only 0.672 , those born between 1913-18 0.795). It is clear, however, that in the immediate future, violent changes in total numbers are unlikely.

There are slight indications that the recovery in average family size after the end of the Second World War was slowing down in the middle 'fifties, but it will be necessary to wait for the 1961 census data before we can be certain of this.

It is not the function of an official census report to speculate upon the causes of the reversal in fertility trends, but the chapter on differential fertility gives information about differentials between occupational groups (both the traditional five-fold classification and the twelve socio-economic groups), between different geographical areas, and also an analysis of fertility differences by differences in the ages of husband and wife. The indices studied are mean family size, proportion infertile and current fertility-rate. These figures confirm the impression that clerical workers, shopkeepers and the lower professional, administrative and managerial groups are now the least fertile section of the population, their fertility being about 20 per cent below that of the population as a whole. On the other hand, semi-skilled and unskilled manual workers continue to show an excess of about the same amount. 